\title{
Dresden Prostate Carcinoma Protein 2
}

National Cancer Institute

\section{Source}

National Cancer Institute. Dresden Prostate Carcinoma Protein 2. NCI Thesaurus. Code C98095.

Dresden prostate carcinoma protein $2(172 \mathrm{aa}, \sim 20 \mathrm{kDa})$ is encoded by the human HMGN2P46 gene. This protein may be involved in the functioning of the prostate. 